\title{
Effect of three storage methods on physical and chemical properties of colostrum from Bos indicus cows
}

\author{
Alexandra Usuga ${ }^{1 *}$ (i) Dana Arroyave Zabala ${ }^{1}$ Luisa Ceballos Medina ${ }^{1}$ \\ David Vallejo Hernandez ${ }^{1}$ Wendy Vera Ramirez ${ }^{1}$ Benjamin Alberto Rojano ${ }^{2}$ (D)
}

${ }^{1}$ Faculty of Veterinary Medicine and Animal Science, CES University, Medellín, Colombia. E-mail: ausuga@ces.edu.co. "Corresponding author. ${ }^{2}$ Faculty of Sciences, School of Chemistry, Universidad Nacional de Colombia, Medellín, Colombia.

ABSTRACT: Maternal colostrum provides the neonate with immunoglobulins, essential for passive immunity. However, storage and handling of colostrum can alter its physical and nutritional characteristics. The aim of this study was to evaluate the effects of three conservation methods on colostrum density, pH, total antioxidant capacity (TAC), protein (PP) and lipid peroxidation (LP). Colostrum samples were collected from $15 \mathrm{Bos}$ indicus cows, and divided into three aliquots for storage using three methods: refrigeration at $4^{\circ} \mathrm{C}$, freezing at $-20^{\circ} \mathrm{C}$, and lyophilization. For each method, four evaluation times were performed: day (d) 5, 10, 15, and 20 for refrigeration and d 15, 30, 45, and 60 for freezing and lyophilization. $\mathrm{pH}$ and density analyses were performed at each evaluation time for each method. On 0 and 15 of storage, TAC, LP, and PP analyses were performed. A generalized linear model, Tukey's test for means comparisons, and a Pearson correlation analysis were conducted. A decrease in refrigerated colostrum $\mathrm{pH}$ was observed on 1 15. Density of the lyophilized colostrum decreased, as compared with that of frozen colostrum. Lyophilization exhibited the lower PP values of samples, whereas refrigeration presented the highest values of $L P$ and PP. No differences in colostrum TAC were observed between storage methods. A positive correlation between PP and colostrum density and a negative correlation between colostrum density and TAC were found. It was concluded that both freezing and lyophilization are suitable storage methods for bovine colostrum, as they limit proteins and lipids oxidation, and maintain the TAC of fresh colostrum. Key words: antioxidant capacity, bovine, milk, oxidation, storage.

Efeito de três métodos de conservação nas propriedades físicas e químicas do colostro de vacas Bos indicus

RESUMO: O colostro materno fornece ao recém-nascido imunoglobulinas que são essenciais para a imunidade passiva. No entanto, o armazenamento e o manuseio do colostro podem alterar suas características físicas e nutricionais. O objetivo deste estudo foi avaliar os efeitos de três métodos de conservação na densidade, $\mathrm{pH}$, capacidade antioxidante total (CAT), peroxidação protéica (PP) e lipídica (LP) do colostro. Amostras de colostro foram coletadas de 15 vacas Bos indicus, e divididas em três alíquotas para armazenamento usando três métodos: refrigeração a $4{ }^{\circ} \mathrm{C}$, congelamento a $-20^{\circ} \mathrm{C}$ e liofilização. Em cada método, foram realizados quatro tempos de avaliação: dia (d) 5, 10, 15 e 20 para refrigeração e dia 15, 30, 45 e 60 para congelamento e liofilização. Além disso, as análises de pH e densidade foram realizadas em cada momento de avaliação para cada método. No dia 0 e 15 de conservação foram realizadas análises da CAT, PL e PP. Foi realizado um modelo linear generalizado, teste de Tukey para comparação de médias e análise de correlação de Pearson. Uma diminuição no pH do colostro refrigerado foi encontrada no dia 15. A densidade do colostro liofilizado diminuiu em comparação com o colostro congelado. A liofilização apresentou menor PP das amostras, enquanto a refrigeração apresentou os maiores valores de PL e PP. Não foram observadas diferenças no TAC do colostro entre os métodos de armazenamento. Foi encontrada uma correlação positiva entre PP e densidade do colostro e uma correlação negativa entre densidade do colostro e CAT. Assim, concluiu-se que tanto o congelamento quanto a liofilização são métodos adequados de armazenamento do colostro bovino, pois limitam a oxidação de proteínas e lipídios e mantêm o TAC do colostro fresco.

Palavras-chave: capacidade antioxidante, bovino, leite, oxidação, armazenamento.

\section{INTRODUCTION}

Colostrum is the first milk secreted by cows after parturition and contains immunoglobulins that are essential for protecting neonatal calves against diseases (CUMMINS et al., 2016b). Because of the manner of bovine placentation, calves are born almost agammaglobulinemic, with a complete but immature immune system (GODDEN et al., 2019). Thus, they need to absorb good-quality colostrum soon after birth to ensure adequate immunoglobulin transfer (MORIN et al., 2021). In the United States, 19.2\% of calves have passive transfer failure and $7.8 \%$ of heifer calves that are born alive die before weaning. 
Providing adequate colostrum is one practice that can improve these rates (MORRILL et al., 2012).

Therefore, employing management practices to ensure that calves receive a sufficient volume of high-quality colostrum on their first day of life is critically important for calf health and future production (HUE et al., 2021). On this basis, colostrum is routinely stored before feeding, in which colostrum is kept in a refrigerator or freezer or at ambient temperatures for an extended period of time (CUMMINS et al., 2016b). CUMMINS et al. (2016a) reported that $90 \%$ of Irish dairy producers store colostrum, while colostrum is routinely stored in $89 \%$ of large dairy farms in North America. Colostrum is traditionally stored in a freezer to prevent composition alterations, such as $\operatorname{IgG}$ concentration and bacterial level changes. However, it has been reported that storing and handling dairy products after harvest and before consumption can alter their physical, nutritional, and bacterial characteristics (FISCHER et al., 2018; GODDEN et al., 2019), as well as other immune properties and bioactive compounds, such as leukocyte concentration, immunoglobulins, whey proteins, and enzymes (XU et al., 2021).

Moreover, storage management may alter the physical properties of colostrum, such as its $\mathrm{pH}$ (CUMMINS et al., 2016a). The pH of colostrum is slightly acidic (pH 6.4) (PUPPEL et al., 2019) and is affected by different buffering properties, such as casein, total protein content, storage conditions (CUMMINS et al., 2016a), and bacterial counts (HYRSLOVA et al. 2020). Although it has been suggested that the rate of $\mathrm{IgG}$ absorption in calves may be affected by the bacteria and $\mathrm{pH}$ of the colostrum, further investigations are necessary for validation (CUMMINS et al., 2016a).

Further, there are no known studies evaluating the effect of storage conditions on colostrum density. Routine on-farm monitoring of colostrum quality is performed using a colostrometer or an optical or digital refractometer, which measures the refractive index of liquids using a Brix score (BARTENS et al. 2016). Although a Brix refractometer measures the total dissolved solids and not IgG specifically (PECHOVA et al., 2019), many studies have observed a close relationship between the IgG content and Brix values in colostrum, and the use of the refractometer has even been recommended to assess the nutrient density of milk (ELSOHABY et al., 2021; KESSLER et al., 2021).

Moreover, not only is colostrum a source of antioxidants, it is also a source of reactive oxygen species (ROS). Specifically, it is rich in macromolecules, such as lipids or proteins, that are easily oxidized and have a significant population of immune cells, including macrophages, that use ROS generating systems to kill bacteria (ABUELO et al., 2014). Newborns are especially susceptible to stress because of changes in oxygen pressure and the start of regular breathing, which may result in a decrease in the efficiency of antioxidative systems. Additionally, their new extrauterine environment may cause factors related to ROS overproduction (ALBERA \& KANKOFER, 2011). Thus, oxidative stress may be a cofactor in the development of many neonatal dysfunctions, leading to serious systemic effects and impaired vitality (PĂDURARU et al., 2018). Some studies have evaluated the antioxidant and oxidative status of cow, sheep, goat, and human colostrum (CLOETENS et al., 2013; PĂDURARU et al., 2018). Overall, total antioxidant capacity (TAC) is an attractive concept for obtaining an overview of the antioxidant potential of plasma and body fluids, as it includes the cumulative action of all the antioxidants, thereby providing an integrated parameter rather than the simple sum of measurable antioxidants (PĂDURARU et al., 2018). ALBERA \& KANKOFER (2011) evaluated the antioxidant and oxidative status of colostrum and milk samples from Holstein-Friesian cows and found that the TAC and glutathione peroxidase values increased $(\mathrm{P}<0.05)$ over the examined time period (from 0 min to $12 \mathrm{~d}$ postpartum). In particular, the index of lipid peroxidation was the highest at $24 \mathrm{~h}$, while it fluctuated between $48 \mathrm{~h}$ and 12 th d post-partum. Similar to that observed for cows, the TAC values in sheep colostrum were the lowest in samples taken immediately after parturition and increased with time (LIPKO-PRZYBYLSKA et al., 2010). However, there are no reports that evaluate these aspects in bovine species while considering the colostrum storage method. Therefore, the aim of this study was to measure the effect of three storage conditions on density, $\mathrm{pH}$, antioxidant capacity, and protein and lipid peroxidation in the colostrum of Bos indicus cows.

\section{MATERIALS AND METHODS}

\section{Sample collection}

Samples of bovine maternal colostrum were collected from the first milking after calving within the first $8 \mathrm{~h}$ from 15 Bos indicus females on a farm in Cimitarra, Santander, Colombia. All cows were multiparous and had ad libitum access to water, Brachiaria grass, and 8\% mineralized salt (Ganasal $8 \%$ - Ganasal con Phosbic $\left.{ }^{\circledR}\right)$. The colostrum was 
collected in a sterile plastic bucket, and then, using a sterile dipper, a $250 \mathrm{~mL}$ sample of colostrum from each cow was collected into a sterile plastic container for storage. The colostrum from each cow was sampled and stored separately. In the fresh colostrum, the $\mathrm{pH}$ and density were evaluated using a $\mathrm{pH}$ meter $\left(\mathrm{Hach}^{\circledR}\right.$, Sension+ PH3) and a digital refractometer (Palm Abbe $^{\mathrm{TM}}$, Misco PA203), respectively. Approximately $50 \mu \mathrm{L}$ of colostrum was placed on a refractometer prism, and the \%Brix (sugar content) was recorded. The refractometer was calibrated with distilled water at the start of each set of analyses. Then, each colostrum sample was transported to the laboratory in a plastic container under refrigeration at $4{ }^{\circ} \mathrm{C}$ for $5 \mathrm{~h}$. At this time, the $\mathrm{pH}$ and density of each sample were measured again.

\section{Establishment of treatments}

In the laboratory, the colostrum from each cow was divided into three aliquots for three different methods of conservation: refrigeration at $4{ }^{\circ} \mathrm{C}$, freezing at $-20{ }^{\circ} \mathrm{C}$, and lyophilization. Before every storage method, the samples were split into four 5 $\mathrm{mL}$ aliquots and placed in sterile $15 \mathrm{~mL}$ individual plastic tubes for sampling at different times (four storage times for each method). For lyophilization, the colostrum samples were stored at $-20{ }^{\circ} \mathrm{C}$ for $24 \mathrm{~h}$ before they were freeze-dried. Colostrum lyophilization was performed according to a modified protocol described by MORETTI et al. (2012), in which the samples were placed in a freeze-drying machine (Labconco Freeze Dry System Freezone Cat. 77,520-00) and exposed to a $30 \mathrm{~h}$ lyophilization cycle at a condenser temperature of $-50{ }^{\circ} \mathrm{C}$ and a vacuum of $25 \times 10^{-3} \mathrm{mbar}$. The lyophilized samples were subsequently stored at $25^{\circ} \mathrm{C}$.

For the refrigerated samples, the evaluation times were d 5, 10, 15, and 20. Conversely, for the frozen and lyophilized samples, the evaluation times were $\mathrm{d} 15,30,45$, and 60 . pH and density analyses were performed at every evaluation time using the previously described methodologies. Meanwhile, lipid, protein peroxidation, and TAC assays were performed on $\mathrm{d} 0$ and 15 for each storage method. For evaluation, the frozen samples were thawed in a warm water bath at $37^{\circ} \mathrm{C}$ and the lyophilized samples were reconstituted in ultrapure water until they reached a volume of $5 \mathrm{~mL}$ for each aliquot.

\section{Colostrum evaluation}

The analyses for lipid peroxidation (LP), protein peroxidation (PP), and TAC were performed in triplicate for each colostrum sample.
Lipid peroxidation (LP). The colostrum LP evaluations were conducted using the modified thiobarbituric acid reactive substance method (TUROLI et al., 2004), in which $50 \mu \mathrm{L}$ of each sample is incubated for $1 \mathrm{~h}$ at $37^{\circ} \mathrm{C}$, and then cooled in ice water for $10 \mathrm{~min}$. Then, $40 \mu \mathrm{L}$ of $15 \%$ trichloroacetic acid (TCA, Sigma-Aldrich), and $80 \mu \mathrm{L}$ of $0.67 \%$ thiobarbituric acid (Sigma-Aldrich) were added. The resultant mixture was stirred, incubated for $20 \mathrm{~min}$ at $90{ }^{\circ} \mathrm{C}$, and cooled in ice water for $10 \mathrm{~min}$. Next, $300 \mu \mathrm{L}$ of butanol (Sigma-Aldrich) was added to each sample and stirred for $1 \mathrm{~min}$. Finally, $300 \mu \mathrm{L}$ was taken from the top layer of the sample and placed in a multiwell plate. The fluorescent complex was read using a LS 55 spectrofluorometer (Perkin Elmer) with an excitation wavelength of $500 \mathrm{~nm}$, a 5 excitation slit, an emission wavelength of $550 \mathrm{~nm}$, and a 15 emission slot. The results were expressed as equivalents of malonaldehyde (nmol of MDA/mL sample).

Protein peroxidation (PP). The colostrum PP evaluations were performed by measuring the carbonyl groups present in each sample. These groups were quantified spectrophotometrically via a reaction with 2,4-dinitrophenylhydrazine (DNPH) at $360 \mathrm{~nm}$ (CELI \& GABAI, 2015). Then, the samples were centrifuged, and the resultant pellets were solubilized in $1 \mathrm{~mL}$ of TCA and centrifuged again (1500 $\mathrm{g}$ for $10 \mathrm{~min}$ ). The pellets were subsequently incubated with $1 \mathrm{~mL}$ of $10 \mathrm{mM}$ DNPH (freshly prepared in $2 \mathrm{M}$ hydrochloric acid in the dark) for $1 \mathrm{~h}$ at room temperature, with stirring every $10 \mathrm{~min}$. Then, $1 \mathrm{~mL}$ of $20 \%$ TCA was added, and the samples were centrifuged at $20000 \mathrm{~g}$ for $3 \mathrm{~min}$. Next, the supernatant was decanted, and the pellets were mixed with $1 \mathrm{~mL}$ of a 1:1 solution of ethanol:ethyl acetate. Subsequently, the pellets were incubated with $1 \mathrm{~mL}$ of $6 \mathrm{M}$ guanidine (prepared in phosphate buffered saline, $\mathrm{pH}$ 6.5) for $15 \mathrm{~min}$ at $37{ }^{\circ} \mathrm{C}$ and centrifuged at $1500 \mathrm{~g}$ for $10 \mathrm{~min}$. Finally, the supernatant was collected, and protein oxidation was estimated using spectrophotometry at $360 \mathrm{~nm}$.

TAC assay. To evaluate the colostrum TAC, a discoloration test of ABTS (2,2'-azi-nobis- [3-ethylbenzthiazoline] -6-sulphonic acid) cationic radical was performed in accordance with the procedure described by MESA-VANEGAS et al. (2010). The ABTS radical was generated by oxidizing $3.5 \mathrm{mM}$ ABTS with $1.25 \mathrm{mM}$ potassium persulfate. A total of $10 \mu \mathrm{L}$ of colostrum and $990 \mu \mathrm{L}$ of the ABTS radical solution were used. After $30 \mathrm{~min}$ of reaction at room temperature in the dark, the change in absorbance according to a reference solution of 10 $\mu \mathrm{L}$ of buffer solution and $990 \mu \mathrm{L}$ of ABTS radical 
solution was measured using a spectrophotometer (6405 UV/Vis, Jenway). After $24 \mathrm{~h}$ of reaction, the absorbance was adjusted using PBS to a $\mathrm{pH}$ of 7.4, at a wavelength of $732 \mathrm{~nm}$ and was compared with a standard curve of Trolox $^{\circledR}$ (6-hydroxy-2,5,7,8-tetramethylchroman-2carboxylic acid), which is an analogue of vitamin E, as a reference antioxidant. Note that the decrease in the radical ABTS solution coloration was attributed to the antioxidants present in the sample.

\section{Statistical analysis}

In this study, a random block design was performed, wherein each sample obtained from each cow was a blocking factor, as each colostrum sample was first divided into three aliquots for the three conservation methods, of which each of these aliquots was further divided into four aliquots for each evaluation time. A generalized linear model was fitted for each colostrum quality parameter (dependent variable). In each statistical model, the fixed effects of the cow, treatment (storage method), and time were considered. The means between treatments (storage method and evaluation time) were compared using a Tukey's test. In addition, a Pearson correlation analysis between colostrum $\mathrm{pH}$, density, and redox variables was performed. Based on the parametric tests employed, data normality was assessed using the Shapiro-Wilk test. The significance level for all assessments was set as $p<0.05$. Herein, the results are expressed as the mean \pm standard error of the mean (SEM). All analyses were conducted using SAS version 9.2 software (SAS Institute, Inc.).

\section{RESULTS}

The $\mathrm{pH}$ and density mean values for fresh maternal colostrum were $6.46 \pm 0.04$ (mean \pm SEM) and $1104.74 \pm 0.95 \mathrm{~g} / \mathrm{L}$, respectively. In the laboratory, after transportation at $4{ }^{\circ} \mathrm{C}$ for approximately $5 \mathrm{~h}$, the means of the $\mathrm{pH}$ and density were $6.28 \pm 0.09$ and $1102.83 \pm 3.33 \mathrm{~g} / \mathrm{L}$, respectively.

No changes were observed in colostrum $\mathrm{pH}$ or density $(\mathrm{P}>0.05)$ at different refrigeration times (Table 1).

The results for $\mathrm{pH}$ and density according to the storage method are shown in figures 1 and 2 , respectively. There are no data for refrigerated colostrum for d 20 because an evident deterioration in the organoleptic characteristics of the samples was observed. Further, a decrease $(\mathrm{P}<0.05)$ in the $\mathrm{pH}$ of the refrigerated colostrum was observed in relation to both the frozen and freeze-dried colostrum on $\mathrm{d}$ 15. Regarding the frozen and lyophilized samples, no significant changes $(\mathrm{P}>0.05)$ were observed in the evaluation times for $\mathrm{pH}$. However, with respect to density, there was a decrease $(\mathrm{P}<0.05)$ in all the measuring times of lyophilized colostrum, as compared with the frozen and refrigerated samples, on d 15.

On day 0 , before placing the colostrum samples into storage, the PP, LP, and TAC results were (mean \pm SEM) $7.99 \pm 0.27$ nmol carbonyls / $\mathrm{mg}$ of protein, $0.59 \pm 0.01 \mathrm{nmol} \mathrm{MDA} / \mathrm{mL}$ of colostrum, and $24.05 \pm 1.34 \mu \mathrm{mol}$ Trolox/L of colostrum, respectively. Overall, the lyophilized colostrum showed a reduction $(\mathrm{P}<0.05)$ in $\mathrm{PP}$, as compared with the refrigerated colostrum, while a reduction $(\mathrm{P}<0.05)$ in $\mathrm{LP}$ was observed for the frozen and lyophilized samples, as compared with the refrigerated colostrum, on $\mathrm{d} 15$. Nevertheless, TAC exhibited no significant change $(\mathrm{P}>0.05)$ (Table 2$)$. Further, no significant differences were observed between the PP, LP, and TAC values on day 0 with those of the stored colostrum on day $15(\mathrm{P}>0.05)$.

The results of the correlation analysis between the redox status of colostrum on day 0 and 15, and $\mathrm{pH}$ and density of the fresh and stored colostrum, according to the storage method, are summarized in table 3 .

Table 1 - Results for $\mathrm{pH}$ and density of bovine colostrum at different refrigeration times.

\begin{tabular}{|c|c|c|c|c|}
\hline \multirow[t]{2}{*}{ Variable } & \multicolumn{4}{|c|}{ 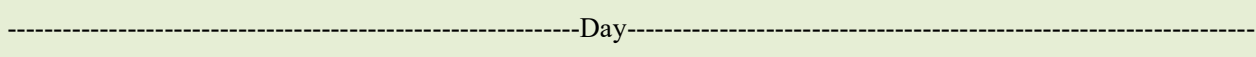 } \\
\hline & 5 & 10 & 15 & 20 \\
\hline $\mathrm{pH}^{1}$ & $6.03 \pm 0.09$ & $6.00 \pm 0.07$ & $6.12 \pm 0.09$ & $5.97 \pm 0.17$ \\
\hline Density $^{2}$ & $1102.53 \pm 3.11$ & $1102.70 \pm 3.25$ & $1098.99 \pm 3.87$ & $1102.03 \pm 3.28$ \\
\hline
\end{tabular}

Results are expressed as means \pm standard error of the mean (SEM).

No statistically significant differences were found $(\mathrm{P}>0.05)$.

${ }^{1} \mathrm{pH}$ : potential for hydrogen $\left(-\log \left[\mathrm{H}^{+}\right]\right)$.

${ }^{2}$ Density: g/L. 


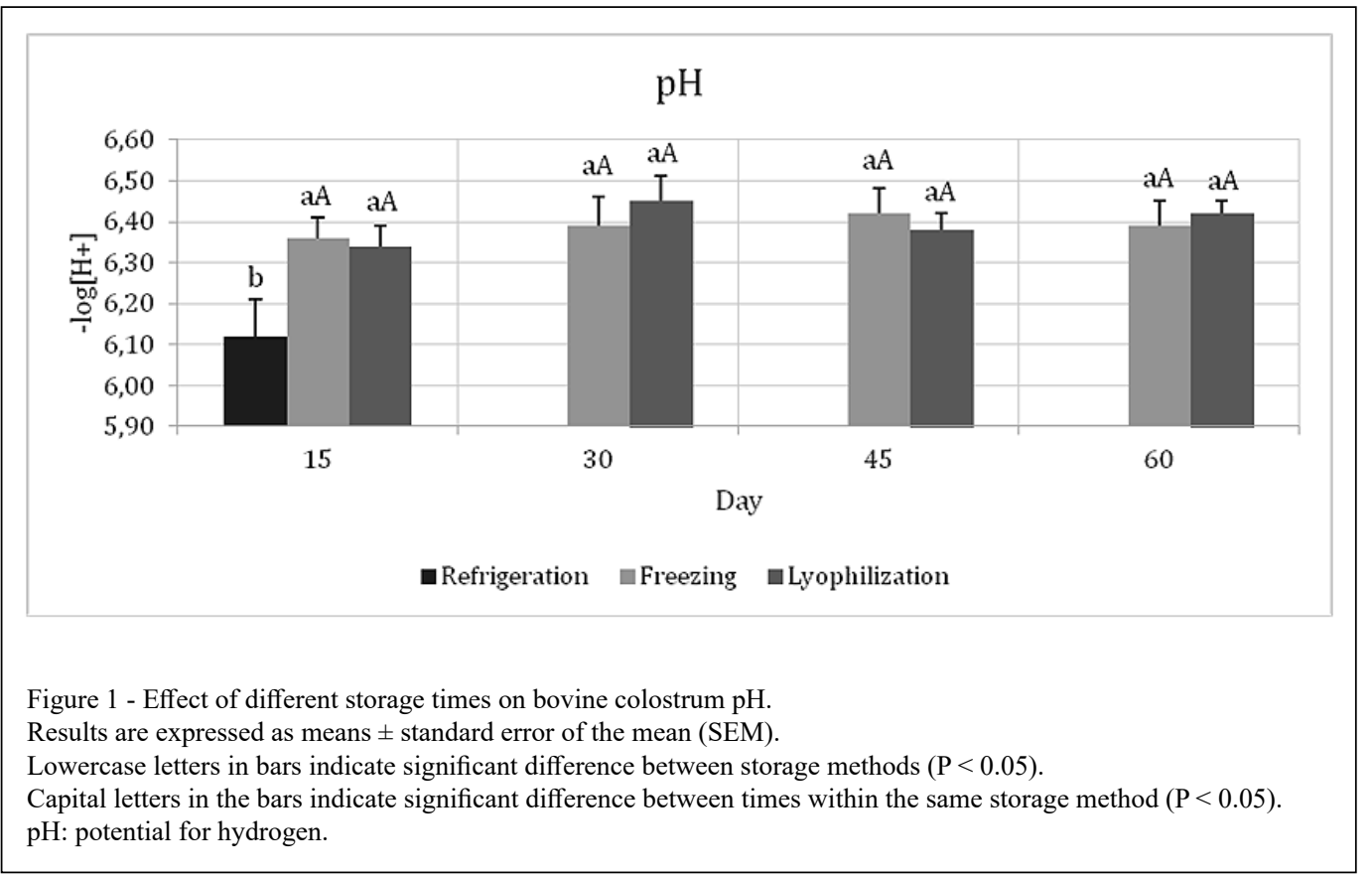

\section{DISCUSSION}

The colostrum storage method in which proteins were the least oxidized was lyophilization. Conversely, the refrigeration method showed a greater oxidation of lipids on day 15 of storage. To date, no studies have investigated the effect of storage methods on the redox status of bovine colostrum. BERTINO et al. (2013) reported that human milk can be stored in controlled refrigerated conditions for as long as $96 \mathrm{~h}$ without evidence of oxidation processes while completely preserving lipase activities, indicating that its nutritive and non-nutritive components are not compromised.

In this study, no significant changes were observed in the colostrum $\mathrm{pH}$ at different evaluation times within the same method. However, a decrease in $\mathrm{pH}$ was observed in the refrigerated colostrum at $\mathrm{d} 15$, as compared with the frozen and lyophilized samples. The $\mathrm{pH}$ of colostrum is affected by different buffering properties, such as casein and total protein content, and is also dependent on the temperature at which the colostrum is stored (CUMMINS et al., 2016b). Similar to our results, CUMMINS et al. (2016b) reported a $\mathrm{pH}$ decrease in colostrum stored at $4{ }^{\circ} \mathrm{C}$ for $72 \mathrm{~h}$. Although previous research has documented a reduction in immunoglobulin absorption in calves fed colostrum at a relatively low pH (FOLEY et al., 1978), QUIGLEY et al. (2000) suggested that a pH as low as 5.0 did not affect the absorption of IgG in calves. In this study, the minimum $\mathrm{pH}$ reported was $5.97 \pm 0.17$, which occurred on $20 \mathrm{~d}$ of colostrum refrigeration.

Most of the protein in colostrum is $\mathrm{IgG}$. Thus, measuring the total protein in colostrum may provide a value that is correlated with the $\operatorname{IgG}$ concentration (MORRILL et al., 2012). BIELMANN et al. (2010) determined that a Brix value of $22 \%$ $(\geq 22 \%$ ) in the refractometer is equivalent to $50 \mathrm{~g} / \mathrm{L}$ of $\mathrm{IgG}$, which represents a good quality colostrum. Herein, the lyophilization method showed a decrease in colostrum density, as compared with the other two storage methods. It has been reported that drying techniques can affect the microstructure of milk, such as the density of the particles, which may have caused this decrease (CARIC \& KALAB, 1987).

Regarding the oxidative state of colostrum, the results herein revealed a decrease in PP in the lyophilized colostrum compared with that in the refrigerated colostrum. Cow colostrum contains more proteins than mature milk (ELFSTRAND et al., 2002). The caseins and whey proteins present in colostrum exert antioxidant activities, as measured by reducing power, ferrous ion chelating abilities, and inhibitory effects on LP (CHIANG \& CHANG, 2005). While the $\mathrm{PP}$ reduction observed in the lyophilized colostrum can be attributed to its density decrease, it also shows that lyophilization may be an advantageous storage method as dehydration can facilitate subsequent processing and handling, prolong shelf life, and 


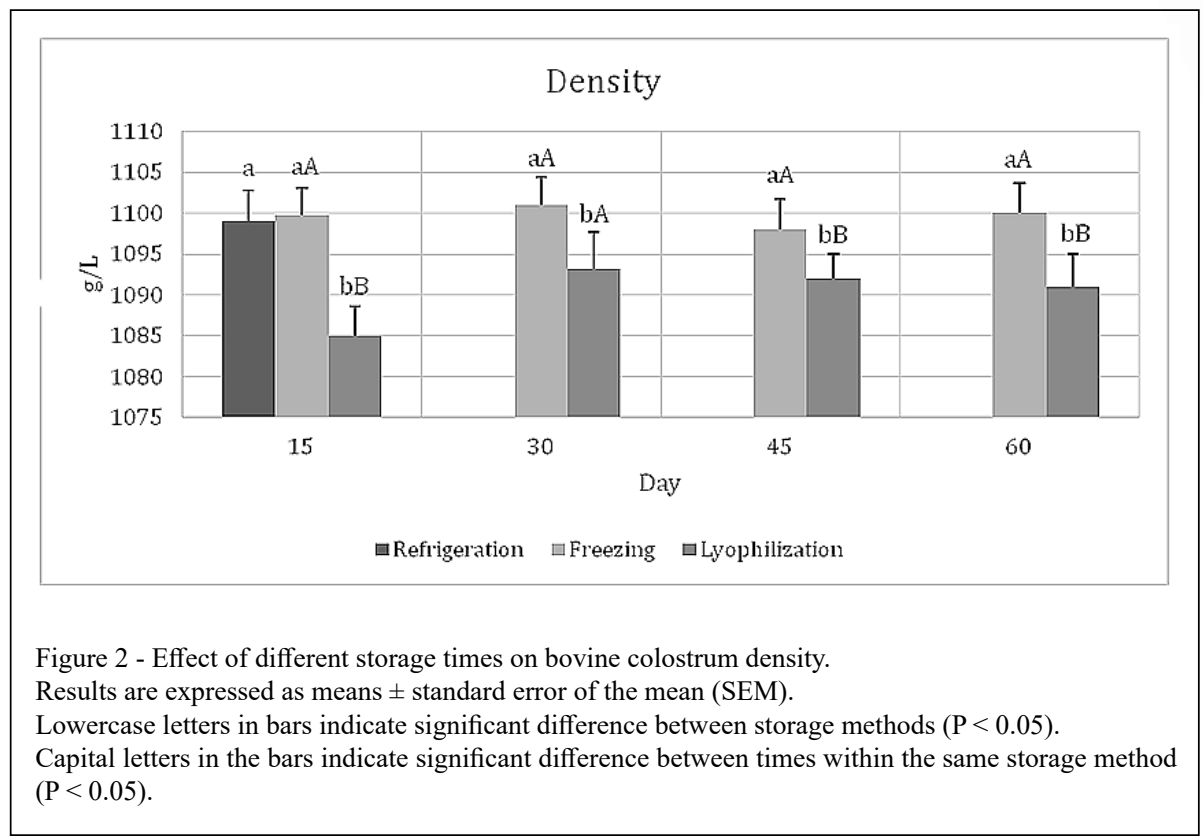

reduce associated costs. Moreover, selecting the appropriate storage condition and packaging material is of great importance to maintaining food quality after drying, as well as extending its shelf life (YU et al., 2015). Although refrigeration and freezing may be less expensive colostrum storage methods for small and medium producers, one disadvantage, especially for refrigerated colostrum, is the increased risk of bacterial contamination, decreased shelf life (TACOMA et al., 2017), and increased costs related to the deterioration of newborn health. Among the alternatives, lyophilized bovine colostrum is the most promising because it can decrease bacterial contamination, extend storage post-harvest, and control infectious agents that could be transmitted to the neonate (MORETTI et al., 2012; LIMA et al., 2013). However, lyophilization requires specific high-cost equipment. Thus, freezing at $-20{ }^{\circ} \mathrm{C}$ is a cheaper option, and could be used as an alternative in the field, as this method showed a reduction in LP with respect to refrigeration, and similar PP results to that of the lyophilized colostrum.

Conversely, colostrum refrigeration achieved the highest PP and LP values of the three storage methods. This may be because many milk components change with storage, some of which have antioxidant properties (HANNA et al., 2004). It has been reported that refrigerating fresh human colostrum for $96 \mathrm{~h}$ maintains its overall lipid composition (BERTINO et al., 2013). However, in this study, the oxidation state was evaluated for a longer period (15 d), which may explain the results obtained. Conversely, ALBERA \& KANKOFER (2011) reported increases in PP and LP in bovine colostrum at $24 \mathrm{~h}$ postpartum.

Several studies have evaluated the TAC of human, ewe, and cow colostrum via the ferric reducing antioxidant power method and ABTS assay (HANNA et al., 2004; TUROLI et al., 2004; LIPKOPRZYBYLSKA et al., 2010; SARI et al., 2012) as colostrum is rich in enzymatic and non-enzymatic antioxidants that can mitigate the oxidative stress to which the neonates are exposed (PANDEY et al., 2011).

By evaluating evaluated TAC colostrum via an ABTS assay on day 7 of refrigeration at $4{ }^{\circ} \mathrm{C}$ and freezing at $-20^{\circ} \mathrm{C}$, HANNA et al. (2004), obtained results of $1.48 \mu \mathrm{mol}$ Trolox/L of colostrum and 1.34 $\mu \mathrm{mol}$ Trolox/L of colostrum, respectively. In this study, higher TAC values were obtained for bovine colostrum under the same storage conditions after $15 \mathrm{~d}$, reaching values of $24.21 \mu \mathrm{mol}$ Trolox $/ \mathrm{L}$ of colostrum and $26.43 \mu \mathrm{mol}$ Trolox/L of colostrum, respectively. This discrepancy may be the result of differences in the components and their quantities present in the colostrum of different species. For example, IgG is the major immunoglobulin class present in ruminant colostrum, whereas IgA is the major immunoglobulin present in human milk (STELWAGEN et al., 2009). According to our results, there was no difference between the TAC of the colostrum preserved by each 
Table 2 - Effect of storage method on bovine colostrum redox status on d (day) 15 .

\begin{tabular}{lcrr}
\hline & PP $^{1}$ & LP $^{2}$ & TAC $^{3}$ \\
\hline Refrigeration & $19.52 \pm 4.14^{\mathrm{a}}$ & $0.69 \pm 0.13^{\mathrm{a}}$ & $24.21 \pm 3.46^{\mathrm{a}}$ \\
Freezing & $14.17 \pm 2.50^{\mathrm{ab}}$ & $0.27 \pm 0.04^{\mathrm{b}}$ & $26.43 \pm 2.53^{\mathrm{a}}$ \\
Lyophilization & $12.59 \pm 2.15^{\mathrm{b}}$ & $0.25 \pm 0.05^{\mathrm{b}}$ & $20.37 \pm 2.57^{\mathrm{a}}$ \\
\hline
\end{tabular}

Results are expressed as means \pm standard error of the mean (SEM).

${ }_{\mathrm{a}, \mathrm{b}}$ Means within a column with different superscripts differ $(\mathrm{P}<0.05)$.

${ }^{1} \mathrm{PP}$ : Protein peroxidation (nmol carbonyls $/ \mathrm{mg}$ of protein).

${ }^{2} \mathrm{LP}$ : Lipid peroxidation (nmol MDA / $\mathrm{mL}$ of colostrum).

${ }^{3} \mathrm{TAC}$ : Total antioxidant capacity ( $\mu \mathrm{mol}$ Trolox/ L of colostrum).

method on $\mathrm{d} 15$, which differs from that reported by HANNA et al. (2004) for human colostrum, who observed a decrease in antioxidant activity under both refrigeration and freezing storage. The data obtained from cow colostrum and milk showed dynamic changes in TAC within $7 \mathrm{~d}$ postpartum (KANKOFER \& LIPKO-PRZYBYLSKA, 2008). However, one study showed that during freezing, lyophilization, and

Table 3 - Pearson's correlation coefficients (upper line) and P-value (lower line) between redox status of colostrum and pH and density of fresh and stored colostrum.

\begin{tabular}{|c|c|c|c|c|c|}
\hline Method & Variable & $\begin{array}{l}\text { Fresh colostrum } \\
\mathrm{pH}\end{array}$ & $\begin{array}{c}\text { Fresh colostrum } \\
\text { density }\end{array}$ & $\begin{array}{c}\text { Stored colostrum } \\
\mathrm{pH}\end{array}$ & $\begin{array}{c}\text { Stored colostrum } \\
\text { density }\end{array}$ \\
\hline \multirow{6}{*}{$\begin{array}{l}\text { Fresh } \\
\text { (Day 0) }\end{array}$} & \multirow{2}{*}{$\mathrm{PP}^{1}$} & -0.9215 & -0.0611 & -0.9327 & 0.0802 \\
\hline & & $<.0001$ & 0.8503 & $<.0001$ & 0.8042 \\
\hline & \multirow{2}{*}{$\mathrm{LP}^{2}$} & 0.1076 & -0.7466 & -0.1252 & -0.7723 \\
\hline & & 0.7829 & 0.0208 & 0.7482 & 0.0147 \\
\hline & \multirow{2}{*}{$\mathrm{TAC}^{3}$} & 0.6677 & 0.1770 & 0.5294 & 0.2069 \\
\hline & & 0.0001 & 0.3771 & 0.0045 & 0.3004 \\
\hline \multirow{6}{*}{ Refrigeration (Day 15) } & \multirow{2}{*}{$\mathrm{PP}^{1}$} & 0.1672 & 0.3981 & 0.3504 & 0.5362 \\
\hline & & 0.5514 & 0.1416 & 0.2003 & 0.0393 \\
\hline & \multirow{2}{*}{$\mathrm{LP}^{2}$} & 0.0818 & -0.0084 & 0.3311 & 0.0494 \\
\hline & & 0.7718 & 0.9762 & 0.228 & 0.861 \\
\hline & \multirow{2}{*}{$\mathrm{TAC}^{3}$} & -0.0729 & -0.4214 & -0.4921 & -0.5710 \\
\hline & & 0.7960 & 0.1177 & 0.0624 & 0.0262 \\
\hline \multirow{6}{*}{$\begin{array}{l}\text { Freezing } \\
\text { (Day 15) }\end{array}$} & \multirow{2}{*}{$\mathrm{PP}^{1}$} & 0.0299 & 0.4815 & -0.2707 & 0.4559 \\
\hline & & 0.9155 & 0.0691 & 0.3291 & 0.0876 \\
\hline & \multirow{2}{*}{$\mathrm{LP}^{2}$} & 0.0967 & -0.4186 & 0.0521 & -0.3319 \\
\hline & & 0.7317 & 0.1204 & 0.8536 & 0.2268 \\
\hline & \multirow{2}{*}{$\mathrm{TAC}^{3}$} & -0.1254 & -0.4625 & -0.0106 & -0.3525 \\
\hline & & 0.6560 & 0.0826 & 0.9698 & 0.1974 \\
\hline \multirow{6}{*}{ Lyophilization (Day 15) } & \multirow{2}{*}{$\mathrm{PP}^{1}$} & -0.1390 & 0.2503 & 0.4056 & -0.0447 \\
\hline & & 0.6211 & 0.3682 & 0.1336 & 0.8741 \\
\hline & \multirow{2}{*}{$\mathrm{LP}^{2}$} & -0.3026 & -0.6141 & -0.5720 & -0.2237 \\
\hline & & 0.2728 & 0.0149 & 0.0259 & 0.4228 \\
\hline & \multirow{2}{*}{$\mathrm{TAC}^{3}$} & 0.2598 & -0.3321 & 0.2126 & -0.3138 \\
\hline & & 0.3497 & 0.2265 & 0.4466 & 0.2546 \\
\hline
\end{tabular}

${ }^{1} \mathrm{PP}$ : Protein peroxidation (nmol carbonyls /mg of protein)

${ }^{2} \mathrm{LP}$ : Lipid peroxidation (nmol MDA / $\mathrm{mL}$ of colostrum).

${ }^{3} \mathrm{TAC}$ : Total antioxidant capacity ( $\mu \mathrm{mol}$ Trolox/ L of colostrum). 
storage of lyophilized colostrum within 12 months, no reduction in antioxidative properties occurred (SANDOMIRSKY et al., 2003). Thus, the type of thermal treatment might affect the TAC. Specifically, it has been reported that severe heat treatments increase the TAC, which might be due to the formation of brown melanoidins (CALLIGARIS et al., 2004). CHEN et al. (2003) found that TAC values, as measured using the ABTS assay, in commercial cow milk ( $3 \%$ fat) were significantly higher than those in cow milk with lower fat percentages $(0.5 \%$ $1.5 \%)$ and defatted milk. Therefore, lipid interference and the reactivity of fat-soluble antioxidants may influence the TAC (CLOETENS et al., 2013).

\section{CONCLUSION}

Overall, it was concluded that both freezing and lyophilization are good methods of bovine colostrum storage, as they exhibit limited protein and lipid oxidation, and the TAC remains the same as that of fresh colostrum. However, freezing colostrum may be a more promising alternative and easier to handle in the field, as it is inexpensive and stable, making it a suitable storage method to produce a bovine colostrum bank, which is an important management tool in commercial operations, to ensure the supply of immunoglobulins to newborn calves.

\section{ACKNOWLEDGMENTS}

The authors would like to thank CES University for its financial support and the Food Science Laboratory of Universidad Nacional de Colombia, Sede Medellín for its technical support.

\section{BIOETHICAL AND BIOSSECURITY COMMITTEE APPROVAL}

The Institutional Committee for the Care and Use of Animals (CICUA) of the CES University in session number 28 on October 23, 2017 approved the experimental protocols of the present study, identified with the project code $\mathrm{N}^{\circ} 157$. While conducting this experiment, the authors fulfilled the Colombian Law 84 of December 1989, Chapter VI (Of the Use of Live Animals in Experiments and Research), Article 26 and Law 1774 of 2016, Article 1.

\section{AUTHOR CONTRIBUTIONS}

All authors contributed equally to the conception and writing of this manuscript. All authors critically reviewed the manuscript and approved the final version of the manuscript.

\section{DECLARATION OF CONFLICT OF INTEREST}

The authors declare no conflict of interest.

\section{REFERENCES}

ABUELO, A. et al. Effect of colostrum redox balance on the oxidative status of calves during the first 3 months of life and the relationship with passive immune acquisition. The Veterinay Journal, v.199, p.245-268, 2014. Available from: <https://doi. org/10.1016/j.tvj1.2013.10.032>. Accessed: Nov. 7, 2020. doi: 10.1016/j.tvj1.2013.10.032.

ALBERA, E.; KANKOFER, M. The comparison of antioxidative/ oxidative profile in blood, colostrum and milk of early postpartum cows and their newborns. Reproduction in domestic animals, v.46, p.763-769, 2011. Available from: <https://doi.org/ 10.1111/j.1439-0531.2010.01737.x>. Accessed: Nov. 2, 2020. doi: 10.1111/j.1439-0531.2010.01737.x.

BARTENS, M. C. et al. Assessment of different methods to estimate bovine colostrum quality on farm. New Zealand Veterinary Journal, v.64, p.263-267, 2016. Available from: <https://doi.org/ 10.1080/00480169.2016.1184109>. Accessed: Oct. 21, 2020. doi: 10.1080/00480169.2016.1184109.

BERTINO, E.M. et al. Effect of prolonged refrigeration on the lipid profile, lipase activity, and oxidative status of human milk. The Journal of Pediatric Gastroenterology and Nutrition, v.56, p.390-396, 2013. Available from: <https://doi.org/10.1097/ MPG.0b013e31827af155>. Accessed: Oct. 21, 2020. doi: 10.1097/ MPG.0b013e31827af155.

BIELMANN, V. J. et al. An evaluation of brix refractometry instruments for measurement of colostrum quality in dairy cattle. Journal of Dairy Science, v. 93, p.3713-3721, 2010. Available from: < https://doi.org/10.3168/jds.2009-2943>. Accessed: Oct. 21, 2020. doi: 10.3168/jds.2009-2943.

CALLIGARIS, S. L. et al. Effect of heat treatment on the antioxidant and prooxidant activity of milk. International Dairy Journal, v.14, p.421-427, 2004. Available from: <https://doi. org/10.1016/j.idairyj.2003.10.001>. Accessed: Nov. 2, 2020. doi: 10.1016/j.idairyj.2003.10.001.

CARIC, M.; KALAB, M. Effects of drying techniques on milk powders quality and microstructure: a review. In: Food Structure, v.6, p.171-180, 1987. Available from: <https://digitalcommons. usu.edu/foodmicrostructure/vol6/iss2/9>. Accessed: Oct. 25, 2020.

CELI, P.; GABAI, G. Oxidant/antioxidant balance in animal nutrition and health: the role of protein oxidation. Frontiers in Veterinary Science, v.2, p.48, 2015. Available from: $<\mathrm{https}$ ://doi. org/10.3389/fvets.2015.00048>. Accessed: Oct. 21, 2020. doi: 10.3389 /fvets. 2015.00048 .

CHEN, J. H. et al. Antioxidant capacity of bovine milk as assayed by spectrophotometric and amperometric methods. International Dairy Journal, v.13, p.927-935, 2003. Available from: <https:// doi.org/10.1016/S0958-6946(03)00139-0>. Accessed: Oct. 21, 2020. doi: 10.1016/S0958-6946(03)00139-0.

CHIANG, S. H.; CHANG, C. Y. Antioxidant properties of caseins and whey proteins from colostrums. Journal of Food and Drug Analysis, v.13, p.57-63, 2005. Available from: <https://www. researchgate.net/profile/ChiYueChang/publication/268375156 Antioxidant_Properties_of_Caseins_and_Whey_Proteins_from_ Colostrums/links/5591 f62 d08ae1e 1fobb00edd/AntioxidantProperties-of-Caseins-and-Whey-Proteins-from-Colostrums.pdf $>$. Accessed: Oct. 21, 2020. 
CLOETENS, L. et al. The antioxidant capacity of milk the application of different methods in vitro and in vivo. Cellular and Molecular Biology, v.59 (1), p.43-57, 2013. Available from: $<$ https://doi.org/10.1170/T946>. Accessed: Oct. 22, 2020. doi: $10.1170 / \mathrm{T} 946$

CUMMINS, C. et al. Questionnaire identifying management practices surrounding calving on spring-calving dairy farms and their associations with herd size and herd expansion. Animal, v.10, p.868-877, 2016a. Available from: < https://doi.org/10.1017/ S1751731116000124>. Accessed: Oct. 22, 2020. doi: 10.1017/ S1751731116000124.

CUMMINS, C. et al. Short communication: The effect of storage conditions over time on bovine colostral immunoglobulin $G$ concentration, bacteria, and pH. Journal of Dairy Science, v.99, p.4857-4863, 2016b. Available from: < https://doi.org/10.3168/ jds.2015-10276>. Accessed: Oct. 21, 2020. doi: 10.3168/jds.201510276 .

ELFSTRAND, L. et al. Immunoglobulins, growth factors and growth hormone in bovine colostrum and the effects of processing. International Dairy Journal, v.12, p.879-887, 2002. Available from: $\quad<$ https://doi.org/10.1016/S0958-6946(02)00089-4> Accessed: Oct. 25, 2020. doi: 10.1016/S0958-6946(02)00089-4.

ELSOHABY, I. et al. Accuracy of direct and indirect methods for assessing bovine colostrum quality using a latent class model fit within a Bayesian framework. Journal of Dairy Science, v.104, n.4, p.4703-4714, 2021. Available from: <https://doi.org/10.3168/ jds.2020-19231>. Accessed: Jun. 25, 2021. doi: 10.3168/jds.202019231.

FISCHER, A. J. et al. The effect of heat treatment of bovine colostrum on the concentration of oligosaccharides in colostrum and in the intestine of neonatal male Holstein calves. Journal of Dairy Science, v.101, n.1, p.401-407, 2018. Available from: $<$ https://pubmed.ncbi.nlm.nih.gov/29102133/>. Accessed: Jun. 24, 2021. doi: $10.3168 /$ jds.2017-13533

FOLEY, J. A. et al. Absorption of colostral proteins by newborn calves fed unfermented, fermented, or buffered colostrum. Journal of Dairy Science, v. 61, p.1450-1456, 1978. Available from: $<$ https://doi.org/10.3168/jds.S0022-0302(78)83748-5>. Accessed: Oct. 21, 2020. doi: 10.3168/jds.S0022-0302(78)83748-5.

GODDEN, S. M. et al. Colostrum management for dairy calves. Veterinary Clinics of North America: Food Animal Practice, v.35, n.3, p.535-556, 2019. Available from: $<$ https://pubmed.ncbi. nlm.nih.gov/31590901>. Accessed: Jun. 24, 2021. doi: 10.1016/j. cvfa.2019.07.005.

HANNA, N. et al. Effect of storage on breast milk antioxidant activity. Archives of Disease in Childhood. Fetal and Neonata Edition, v. 89, p.518-520, 2004. Available from: <http://doi. org/10.1136/adc.2004.049247>. Accessed: Oct. 25, 2020. doi: 10.1136/adc.2004.049247.

HUE, D. T. et al. Colostrum source and passive immunity transfer in dairy bull calves. Journal of Dairy Science, v.104, n. 7, p.81648176, 2021. Available from: <https://doi.org/10.3168/jds.202019318>. Accessed: Jun. 24, 2021. doi: 10.3168/jds.2020-19318.

KANKOFER, M; LIPKO-PRZYBYLSKA. J. Physiological antioxidative/oxidative status in bovine colostrum and mature milk. Acta Veterinaria-Beograd, v.58, p.231-239, 2008. Available from: < https://doi.org/10.2298/AVB0803231K>. Accessed: Oct. 21, 2020. doi: 10.2298/AVB0803231K.

KESSLER, E. C. et al. Short communication: Comparative estimation of colostrum quality by Brix refractometry in bovine, caprine, and ovine colostrum. Journal of Dairy Science, v.104, n.2, p.2438-2444, 2021. Available from: <https://pubmed.ncbi. nlm.nih.gov/33246611/>. Accessed: Jun. 25, 2021. doi: 10.3168/ jds.2020-19020

LIMA, A. L. et al. Eletrophoretic profile of serum proteins of goat kids fed with bovine colostrum in natura and lyophilized. Small Ruminant Research, v.113, n.1, p.278-282, 2013. Available from: $<$ https://doi.org/10.1016/j.smallrumres.2013.02.013>. Accessed: Jul. 13, 2021. doi: 10.1016/j.smallrumres.2013.02.013.

LIPKO-PRZYBYLSKA, J. et al. Comparison of antioxidant defense parameters in colostrum and milk between Berrichon du Cher ewes and Uhrusk ewes. Journal of Dairy Research, v.77, p.117-122, 2010. Available from: <https://doi.org/10.1017/ S0022029909990458>. Accessed: Oct. 25, 2020. doi: 10.1017/ S0022029909990458

MESA-VANEGAS, A. M. et al. Actividad antioxidante y contenido de fenoles totales de algunas especies del género Calophyllum. Revista Cubana de Plantas Medicinales, v.15, p.13-26, 2010. Available from: <http://scielo.sld.cu/scielo.php?script=sci_arttext \&pid=S1028-47962010000200003 > . Accessed: Oct. 26, 2020.

MORETTI, D. B. et al. Lyophilized bovine colostrum as a source of immunoglobulins and insulin-like growth factor for newborn goat kids. Livestock Science, v.145, p.223-229, 2012. Available from: <https://doi.org/10.1016/j.livsci.2012.02.007>. Accessed: Oct. 25, 2020. doi: 10.1016/j.livsci.2012.02.007.

MORIN, M. P. et al. A herd-level study on colostrum management factors associated with the prevalence of adequate transfer of passive immunity in Québec dairy herds. Journal of Dairy Science, v.104, n.4, p.4914-4922, 2021. Available from: <https:// pubmed.ncbi.nlm.nih.gov/33516548/>. Accessed: Jun. 24, 2021 doi: $10.3168 /$ jds.2020-19476.

MORRILL, K. M. et al. Estimate of colostral immunoglobulin $\mathrm{G}$ concentration using refractometry without or with caprylic acid fractionation. Journal of Dairy Science, v.95, p.3987-3996, 2012. Available from: <https://doi.org/10.3168/jds.2011-5104>. Accessed: Nov. 2, 2020. doi: 10.3168/jds.2011-5104.

NGUYEN, T. X. et al. Effects of low $\omega 6: \omega 3$ ratio in sow diet and seaweed supplement in piglet diet on performance, colostrum and milk fatty acid profiles, and oxidative status. Animals. 2020; 10(11):2049. https://doi.org/10.3390/ani10112049.

PĂDURARU, L. et al. Total antioxidant status in fresh and stored human milk from mothers of term and preterm neonates. Pediatrics \& Neonatology, v.59, n.6, p.600-605, 2018. Available from: $<$ https://doi.org/10.1016/j.pedneo.2018.02.004>. Accessed: Jun. 25, 2021. doi: 10.1016/j.pedneo.2018.02.004.

PANDEY, N.N. et al. Bovine colostrum: A veterinary nutraceutical. Journal of Veterinary Medicine and Animal Healt, v. 3, p.3135, 2011. Available from: <http://www.academicjournals.org/ JVMAH>. Accessed: Oct. 25, 2020.

PECHOVA, A. S. et al. Evaluation of colostrum quality in the Czech Republic using radial immunodiffusion and different types 
of refractometers. Veterinarni Medicina, v.64, p.51-59, 2019. Available from: <https://doi.org/10.17221/122/2018-VETMED>. Accessed: Nov. 2, 2020. doi: 10.17221/122/2018-VETMED.

PUPPEL, K. et al. Composition and Factors Affecting Quality of Bovine Colostrum: A Review. Animals, v. 9, n. 12, p.1070 2019. Available from: <https://www.ncbi.nlm.nih.gov/pmc/ articles/PMC6940821/>. Accessed: Jun. 25, 2021. doi:10.3390/ ani9121070.

QUIGLEY, J. D. et al. Short communication: Effect of $\mathrm{pH}$ on absorption of immunoglobulin $\mathrm{G}$ in neonatal calves. Journal of Dairy Science, v.83, p.1853-1855, 2000. Available from: $<$ https:// doi.org/10.3168/jds.S0022-0302(00)75056-9>. Accessed: Oct. 26, 2020. doi: 10.3168/jds.S0022-0302(00)75056-9.

SANDOMIRSKY, B. P. et al. Antioxidative properties of lactoferrin from bovine colostrum before and after its lyophilization. Cryo Letters, v. 24, p.275-280, 2003. Available from: <https://pubmed. ncbi.nlm.nih.gov/14566387/>. Accessed: Oct. 26, 2020. PMID: 14566387.

SARI, F. N. et al. Antioxidant capacity of fresh and stored breast milk is $-80{ }^{\circ} \mathrm{C}$ optimal temperature for freeze storage. The Journal of Maternal-Fetal \& Neonatal Medicine, v.25, p.777-782, 2012. Available from: <https://doi.org/10 3109/14767058.2011.592230>. Accessed: Oct. 26, 2020. doi: $10.3109 / 14767058.2011 .592230$
STELWAGEN, K.E. et al. Immune components of bovine colostrum and milk. Journal of Animal Science, v.87, p.3-9, 2009. Available from: <https://doi.org/10.2527/jas.2008-1377>. Accessed: Oct. 26, 2020. doi: 10.2527/jas.2008-1377.

TACOMA, R. et al. Exploration of the bovine colostrum proteome and effects of heat treatment time on colostrum protein profile. Journal of Dairy Science, v.100, n.11, p.9392-9401. Available from: <https://pubmed.ncbi.nlm.nih.gov/28918156/>. Accessed: Jul. 13, 202. doi: 10.3168/jds.2017-13211. Epub 2017 Sep 13. PMID: 28918156; PMCID: PMC6350923.

TUROLI, D. et al. Determination of oxidative status in breast and formula milk. Acta Paediatrica, v.93, p.1569-1574, 2004. Available from: $\quad<$ https://doi.org/10.1111/j.1651-2227.2004.tb00845.x > Accessed: Oct. 26, 2020. doi: 10.1111/j.1651-2227.2004.tb00845.x.

XU, W. et al. Heat treatment of bovine colostrum: effects on colostrum metabolome and serum metabolome of calves. Animal. The international journal of animal biosciences, v.15, n.4, p.100180, 2021. Available from: <https://doi.org/10.1016/j.animal.2021.100180>. Accessed: Jun. 24, 2021. doi: 10.1016/j.animal.2021.100180.

YU, H. et al. Shelf life and storage stability of spray-died bovine colostrum powders under different storage conditions. Journal of Food Science and Technology, v.52, p.944, 2015. Available from: $<$ https://doi.org/10.1007/s13197-013-1046-3>. Accessed: Oct. 27, 2020. doi: 10.1007/s13197-013-1046-3. 